\title{
Supply Chain Management Integration: Critical Problems and Solutions
}

\author{
Kabossa A.B. Msimangira \\ Department of Higher Education - Business, Faculty of Business, Hospitality and Personal Services, \\ Northern Melbourne Institute of TAFE (Australia) \\ E-mail: KabossaMsimangira@nmit.edu.au (Corresponding Author) \\ Sitalakshmi Venkatraman \\ Department of Higher Education - Business, Faculty of Business, Hospitality and Personal Services, \\ Northern Melbourne Institute of TAFE (Australia) \\ E-mail: SitaVenkat@nmit.edu.au
}

\begin{abstract}
Over the last decade, supply chain management (SCM) has been studied extensively, and its importance to practitioners and academics has received a high level of recognition. However, despite major investments in SCM and supply chain integration (SCI), recent surveys indicate that businesses are struggling to achieve competitive advantage due to SCI silos. This urges us to investigate the emerging concept of SCM integration (SCMI) that is aimed to integrate various traditional supply chains (SC) across intra and interorganisational processes in practice. While there is enormous information on SCM, little is known about the supply chain management integration (SCMI) problems and possible solutions that could be identified through open discussions and brainstorming among management executives of various organisations. This paper presents the results of an exploratory study of SCMI practices via an on-line forum conducted with supply chain personnel in New Zealand. This study identified the organisations' SCM integration problems and possible solutions. The analysis reveals the major problems that are critical to be addressed and the recommended solutions, including: SCMI requires a holistic approach; two-way communication; written service level agreements; relationship management; use of new technologies and integrated software systems; strategic alliances and trust; integrated processes; effective partnership; and predictive cost/benefit analysis of SCM. The insights on the critical problems and solutions provide valuable information on business risks and uncertainty as well as recommendations to effectively employ SCM analytics for sustainability in the global market environment. We developed a SCM analytics framework for SCM integration.
\end{abstract}

Keywords: supply chain management integration, supply chain, problems and solutions, SCM analytics, sustainability

\section{INTRODUCTION}

Supply chain management (SCM) links a firm with its customers, suppliers and other members of the supply chain system, including transportation and warehousing companies. Handfield and Nichols (2002, p. 8) state that supply chain involves all activities associated with the flow and transformation of goods from the raw materials stage (extraction), through to the end user, as well as the associated information flows. However, Mentzer et al. (2001) define a supply chain as three or more of the flows of products, services, finances, and/or information from a source to a customer. The management of the supply chain is basically management of the relationships and activities among the members of organisations (system). The goal of supply chain management is for members in the organisations to work together and build a partnership with each other to increase the competitive advantage of the supply chain as a whole (Mentzer et al., 2001). The concept of SCM is also addressed by Themistocleous et al. (2004) who define SCM as the integrated management of business links, information flows and people. Bowersox et al. (1999) have classified integration in supply chain context into six different types: customer integration, internal integration, material and service supplier integration, measurement integration, technology and planning integration, and relationship integration. For more than a decade SCM literature has been emphasizing on the importance of SCI among intra or inter-organisation processes (e.g., Yuva, 2000; Lee and Wolfe 2003; Richey et al., 2009; Flynn et al., 2010) and the cost-benefit analysis and performance metrics of supply chain (Delaney, 2000; Olugu \& Wong, 2009; Venkatraman \& Nayak, 2010; Zhou et al., 2011). All these researchers are focusing on a particular area (s) or function, and recent studies confirm that barriers still exist and businesses do struggle to adapt various SCI models to suit their needs (Bakker et al., 2012; Georgise et al., 2012). While supply chain integration (SCI) is being attempted to some extent with a goal to combine supply chain functions to improve efficiencies and reduce cost, focusing on the integration of various supply chains independently as silos may not improve performance directly. A broader SCM cross-functional integration is required with a holistic approach and the problems in SCMI need to be identified.

The information regarding an open discussion by the supply chain personnel via an online forum that is exploratory in nature in order to identify SCM integration (SCMI) problems and solutions is scarce in the literature. Furthermore, in the context of New Zealand (NZ) few studies have been done on SCI and they conform to having a specific focus on integrating only certain functional areas (Campbell, 2002; Campbell \& Sankaran, 2005; Vilasini et 
al., 2012). Although SCI research has been conducted in $\mathrm{NZ}$, but little is known about exploratory investigations on supply chain management integration (SCMI) issues and challenges faced by various NZ companies. This research gap shows that such an exploratory approach of SCMI is very important in NZ as well as in other countries to gain a better understanding of the SCMI problems and viable solutions in different business scenarios.

\section{RELATED WORK ON SCM, SCI AND SCMI}

Supply chain management (SCM) has received a great deal of attention over the past decade as a means of increasing national wealth and corporate competitiveness (Lummus and Vokurka, 1999; Hsu et al., 2009; Jabbour et al., 2011). Studies conducted in the U.S reveal that the costs of logistics services, including transportation, inventory holding as well as related administrative charges account for 10-13 percent of gross domestic product (GDP) in most developed countries and regions around the world (Delaney, 1999; Koh et al., 2007; Chong et al., 2011; Valmohammadi, 2013). Many investigations in the past decade confirm that supply chain integration creates value through improved customer service levels, operational performance and reduced costs (Stank et al., 2001; Hsu et al., 2009; Miguel \& Ledur, 2011).

There are many good examples of companies in the literature that have benefited from SCM. Companies such as Dell, General Electric, Cisco and Ford have reported significant benefits in the implementation of SCM concept (Lee \& Whang, 1999; Towill et al., 2000). Furthermore, Simchi-Levi et al. (2003, p. 10) provide three examples of companies implementing supply chain and state that "the National Semiconductor, Wal-Mart, and Procter \& Gamble success stories demonstrate not only that integrating the supply chain is possible, but it can have a huge impact on the company's performance and market share." However, recent estimates of supply chain implementations worldwide highlighted that only $10 \%$ of supply chains are well integrated (Chatzoudes \& Chatzoglou, 2011; Oliva \& Watson, 2011; Vilasini et al., 2012).

The importance of supply chain integration (SCI) has been acknowledged in the literature. Lambert et al. (1998) define SCM as "integration of business". The National Research Council (2000, p. 27) provides a comprehensive definition of SCI as "an association of customers and suppliers who, using management techniques, work together to optimize their collective performance in the creation, distribution, and support of an end product manufacturer". They also stress that supply chain integration is a continuous process that can be optimized only when original equipment manufacturers (OEMs), customers and suppliers work together to improve their relationships and when all participants are aware of key activities at all levels in the chain. This leads to an important and emerging concept of SCMI that fosters "integration across inter and intraorganisational business functions and processes" (Power, 2005; Msimangira, 2006; Boehme et al., 2011). A summary of related work on SCM, SCI and SCMI are described next.

A study conducted by Basnet et al. (2003) reported that the situation is no better in New Zealand and confirms that
NZ is lagging behind the US and Europe. Basnet et al (2003, p. 63) noted that in NZ, “... there has not been much progress when it comes to more advanced ideas such as supply chain teams, or information sharing, or use of EDI, etc." They concluded from their survey data that future research opportunities existed in the identification and validation of SCM technique and practices that are particularly suited to manufacturing industries in NZ. The sample study by Power (2005) of the literature review relating to the integration and implementation of SCM practices revealed that "an important emergent theme from the literature is the importance of taking a holistic view and the systemic nature of interactions between the participants" in the supply chain. A study conducted by Pagell (2004) on the drivers of internal integration revealed that internal integration is a complex issue driven by a number of factors including the structure and culture at the plant, reward systems and the amount of formal and informal communication across the functions. Although internetbased supply chain integration has been praised in the literature, Fronhlich (2002) found the following from the study:

(i) A positive link between e-integration and performance; and

(ii) Internal barriers impeded e-integration more than either upstream supplier barriers or downstream customer barriers.

Sahay \& Mohan (2003) argue that "an increase of uncertainty or supply networks, globalization of businesses, proliferation of product variety and shortening of product life cycles have forced Indian organisations to look beyond their four walls for collaboration with supply chain partners". They recommended that "the Indian industry should align supply chain strategy with the business strategy, streamline processes for supply integration, form partnership for minimizing inventory and focus on infrastructure and technology deployment to build an Indian specific supply chain". Ho \& Chi (2005) state that applying e-commerce solutions to the SC can increase the efficiency of coordination and resource integration among partners, and emphasize that there is a need to monitor and assess supply-chain performance to ensure that the objective of supply chain integration is met. Shen (2005, pp. 58) proposes that "in a growing complexity but abundant opportunities accelerated by globalization and information technologies, companies need to closely integrate themselves into the supply network, carefully manage the complexity that ensues, align their business strategy with supply chain operation, leverage information technology with process improvement, and pioneer operational innovation for superior firm performance". The study of logistics and supply chain practices of Australian and NZ firms by Mollenkopf and Dapiran (2005) reveals that the majority of the firms still focus their efforts on internal logistics integration issues. However, Donk \& Vaart (2005) argue that uncertainty enhances the need for more integration, while shared resources limit the chances of reaching a high level of integration.

The study by Bagchi \& Chun (2005) report that supply chain integration influences operational performance and the extent of integration also has an impact on cost and efficiency. The importance of SCI for improving firm 
performance has been of recent interest among researchers and practitioners to achieve corporate sustainability (Richey, et al. 2009; Msimangira, 2010; Ou et al., 2010; Flynn, et al., 2010; Basnet \& Wisner, 2012; Venkatraman \& Nayak, 2014). However, there are various issues in SCI and the integration problems have been highlighted by many researchers in the literature. A site-based longitudinal case study undertaken with four New Zealand-based companies reveal that supply chain managers tend to pursue integration pathways that are favoured by senior management rather than based on best practice recommendations (Boehme et al., 2011). In a more recent work, Manzouri et al. (2011) report the lack of information across the supply chains as a major difficulty faced by Iranian and Malaysian companies. Msimangira \& Tesha (2014) have explored the global SCM practices and the risks faced by developing countries and found that lack of integration among all the supply chains is a key problem.

An emerging concept of supply chain management integration (SCMI) that promotes SCI across all the intra or inter-organisation processes is aimed at addressing the prevailing situation of supply chain silos and the issues of SCI (Msimangira, 2006; Boehme et al., 2011). Some attempts have been made to consider cross-functional integration of supply chains that would empower management to make decisions about planning and implementation of a successful SCMI. Recent studies have emphasised on using decision support system (DSS) model that could integrate the information flow in only specific functional components of SCM. Miah et al. (2013) have proposed such a DSS approach to address a complex supplier selection decision in healthcare purchasing. They further raised the need for a DSS that incorporates SCMI for achieving an enhanced and accurate decision-making. For instance, changes or introduction of new e-business technologies cause changes in supply chain and networks, and these changes call for a dynamic approach to integrate the supply chains (Kähkönen et al., 2013). Venkatraman \& Nayak (2014) have proposed an information systems (IS) approach to integrate the triple bottom line elements in supply chain for corporate sustainability. Though recent literature has reported the need for SCMI, there is lack of research investigating the problems in implementing such an SCMI.

Overall, studies have revealed that there is no one model that fits all for SCMI, despite efforts have been made to provide some common framework for SC. This is because; the standard metrics and benchmarks in such approaches, including Supply-Chain Operations Reference (SCOR) and Balanced Score Card (BSC) seem inflexible to cater to individual businesses (Wong \& Wong, 2007; Soni \& Kodali, 2010; Georgise et al. 2012). SCM executives face unique practical challenges with the implementation of SCMI to be in line with the overall corporate business strategy (Richey et al., 2009; Hussain \& Nassar, 2010; Bakker et al., 2012; Otchere et al., 2013). This paper explores such practical challenges and the possible solutions for SCMI. It emphasizes the importance to investigate the practical problems faced by the supply chain personnel in the SCMI that would lead to possible solutions that are more effective to be implemented in their own business scenarios.

\section{THE MAIN PURPOSE OF RESEARCH}

The competition in the global market environment has forced companies to examine their corporate strategies regarding supply chain management integration (SCMI) in order to enhance companies' performance (Flynn et al., 2010; Chatzoudes \& Chatzoglou, 2011; Miah et al., 2013). While organisations are able to achieve certain components of supply chain integration, many researchers have reported continuing lack of supply chain management integration across both inter- and intra-organisational supply chains holistically (Boehme et al., 2011; Georgise et al., 2012). Even similar companies adopt different supply chain integration pathways and are in different stages of progress. Some companies are more successful in achieving external integration than internal integration (Halldorsson et al., 2008; Bakker et al., 2012), while others suffer from external integration issues (Msimangira, 2010; Vilasini et al., 2012). Hence, the problems faced by the supply chain personnel in trying to achieve inter- and intra-organisational SCMI require prime attention and this study aims to shed further light in this context. The main purpose of this study is:

- to explore SCMI problems faced by the supply chain personnel in the NZ companies; and

- to identify SCMI solutions that the supply chain personnel consider feasible to implement.

The research question is "What are the supply chain management integration problems and possible solutions in an organisation?"

\section{RESEARCH METHODOLOGY}

This paper reports the exploratory part of the on-going research and therefore, a case study methodology was appropriate, using grounded theory (Glaser \& Strauss, 1967) as the theoretical basis. "The grounded theory approach is a general methodology of analysis linked with data collection that uses a systematically applied set of methods to generate an inductive theory about a substantive area" (Glaser, 1992, p. 16). We allowed the participants in this research to discuss SCMI problems and possible solutions until no new ideas emerged. We provide the conceptual research model of the exploratory part of our study in Figure 1. The model emphasises on exploring the internal and external SC integration issues as well as inter and intra-organisational SCM integration issues, and their differences and synergies in relation to alignment with the enterprise strategy and SCM philosophy of the organisation. Such a model would provide scope for determining the performance of the organisation in terms of achieving a sustainable SCMI strategy of the organisation.

From the exploratory framework of this study depicted in Figure 1, the main focus of this paper is limited to general SCMI practices, with emphasis on exploring the problems and determining practical solutions perceived by the supply chain personnel of the organisations in New Zealand. Hence, the aim of this paper is not to generate theory concerning the SCMI but to provide a framework for an SCMI strategy implementation. The main purpose is to generate a preliminary model for SCMI performance evaluation of an organisation and provide recommendations 
based on the exploratory study we have conducted with the supply chain personnel in New Zealand organisations.

We propose our preliminary model for SCMI performance evaluation by identifying major problems and solutions that would influence the SCMI of an organisation. This model is depicted in Figure 2 and shows how the organisation's SCMI performance could be affected based on the SCMI domino effect on one hand, and the dynamic situation of their business risks on the other. Our model provides the means for identifying the influencing factors on SCMI integration problems and the influencing drivers for possible solutions. The performance evaluation model would facilitate in identifying various internal and external SC silos as well as integration issues and solutions towards achieving cross boundary integration across inter and intraorganisation for a successful SCMI implementation in an organisation.

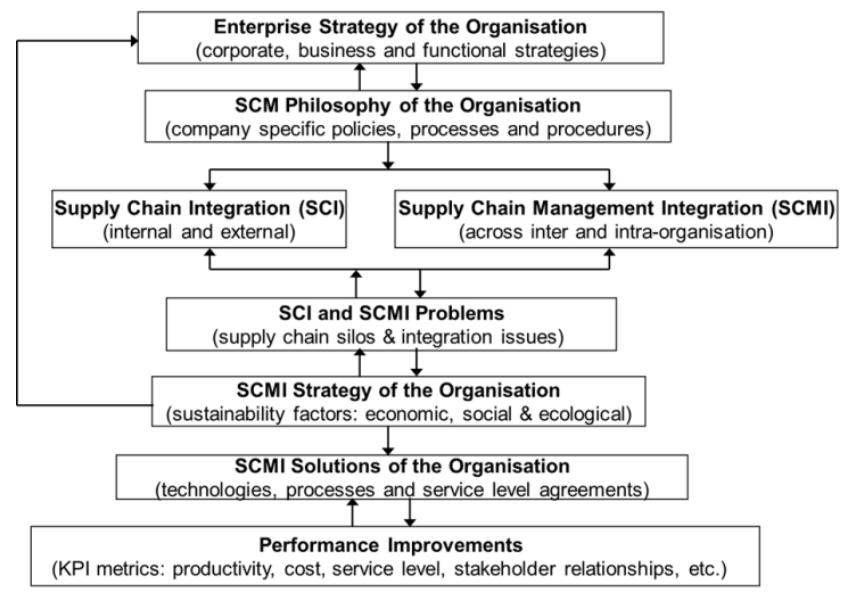

Figure 1 A Conceptual Model for Exploring Supply Chain Management Integration (SCMI) in an Organisation

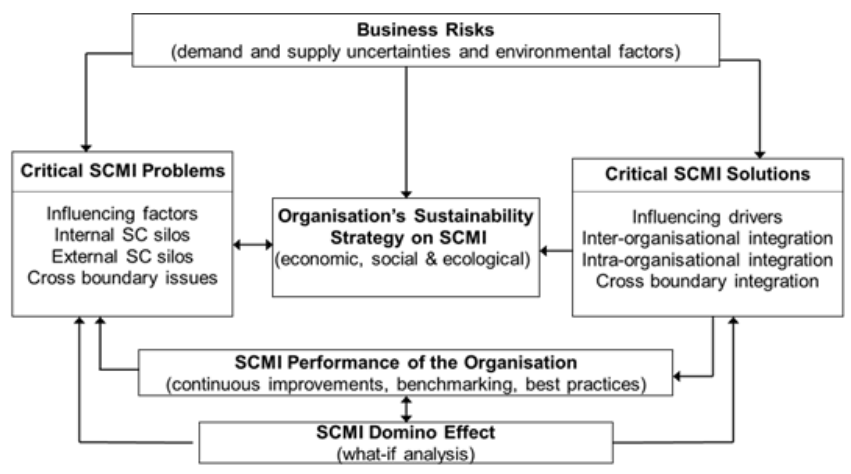

Figure 2 A Preliminary SCMI Performance Evaluation Model of an Organization

\subsection{Selection of Participants}

We used a convenience sample in this study. Information was obtained from the on-line forum participants using a structured discussion format. The participants, purchasing and supply chain personnel were full-time employees, and they studied part-time the Graduate Diploma in Supply Chain Management at the Open Polytechnic of New Zealand. Fourteen participants were invited to participate in the forum, but only ten participants provided in-depth responses to the online forum questions.

\subsection{Data Collection}

Online Internet forum discussion using Moodle learning system was the primary data collection method. The participants were asked to discuss the nature of SCMI in their companies, cite the problems they were facing in their own companies, and propose solutions to enhance SCMI in their companies. Participants were not required to reveal the names and size of their companies for confidentiality. Each participant had access to others' contributions after posting his / her ideas first. The online discussion continued for three weeks and the participants repeatedly posted their ideas in the forum until the discussion was saturated. Repeated discussion ensured reliability of the data (Eisenhardt \& Graebner, 2007). During the forum discussion, the principal investigator acted as a moderator. The main roles were to oversee the communication activities of the participants in the forum, monitoring the contributor's discussion making sure that illegal materials or inappropriate language are not used. More importantly, the moderator was responsible for maintaining the integrity of the forum. For example, the participants were not supposed to reveal the names of the organisations under discussion. The moderator emphasised on the confidentiality of names of people and organisations.

\subsection{Data Analysis}

The open discussion forum was a useful means of collecting in-depth and detailed information in an exploratory manner. In order to make sure that all the important information concerning SCMI was captured and sorted, the process of open coding was used (Strauss and Corbin 1998). The most important task in the analysis was to identify common themes in the forum relating to SCMI practices, problems and solutions.

\section{FINDINGS AND RECOMMENDATIONS}

The results of this study show that the critical SCMI problems in the organizations are as follows:

(i) Insufficient training and competence levels required to maintaining existing SC operations, and to support implementation of new technologies/efficiencies $(50 \%$ of respondents);

(ii) Communication breakdown: lack of effective communication between SC members, especially primary members ( $40 \%$ of respondents);

(iii) Lack of internal cost efficiency and speed of delivery in the areas of ordering, inventory, marketing, and logistics (40\% of respondents); and

(iv) Some members of the supply chain are dominant in the business relationship. Lack of trust, communication is limited or formal, and information sharing becomes secretive. This leads to quality problems (40\% of respondents).

The major problems identified in the forum are provided in Table $\mathbf{1}$ of Appendix. Although similar problems have been identified in the literature, most of the problems identified are discrete. The results of this study show that the critical SCMI problems in the organisations are bundled attributing to silos of internal or external supply chains. 
The respondents were also asked in the online forum to propose major SCMI solutions for their companies (see Table 2 of Appendix). The critical solutions proposed by the respondents are indicated below:

(i) Two-way communication is needed, and everyone involved in the SCMI must be aware of the structure and processes involved in the SC. Information sharing is important (60\% of respondents);

(ii) Integrating key members' operations of the supply chain requires a holistic approach and adoption from top executives to shop floor members for efficient and effective change ( $40 \%$ of respondents); and

(iii) Form strategic alliances with SC members, and foster an open and honest culture (30\% of respondents).

The SCM personnel proposed that integrating key members' interactions of the $\mathrm{SC}$ requires a holistic approach (40\% of the respondents). This supports the results of the cross-section literature review by Power (2005). Power states that "an important emergent theme from the literature is the importance of taking a holistic view, and the systemic nature of interactions among the participants" in the supply chain.

The insights on the problems and solutions provide valuable information on business risks and uncertainty for sustainability in the global market environment. For example, uncertain source of supply, uncertain demand caused by unknown requirements of the customers, and more importantly, other internal and external environmental factors contribute towards the influencing factors that affect the SCMI, as provided in Figure 2. The critical problems, critical solutions, and the organisation's corporate strategy on SCMI have an impact on performance. Also, demand and supply uncertainties, and other environmental factors cause business risks that have an impact on the corporate, business and functional strategies of the organisation.

The lesson learned from this study is that there is a SCMI domino effect between critical problems, critical solutions, organisation's performance, organisation's corporate strategy, and the environmental uncertainties/ risks. For this paper, domino effect (DE) in SCMI is caused by adapting a critical solution, which if not properly implemented causes other critical problems, overall affecting the organisation's sustainability strategy on SCMI. Unsolved problems cause other problems in the competitive global business environment. We propose that such a SCMI domino effect could be minimised through effective adoption of SCM analytics to achieve integration across inter and intra-organisational processes and relationships.

As an outcome of this exploratory study, we propose a framework for SCM analytics that incorporates descriptive, predictive and prescriptive analytics. We recommend our proposed SCM analytics framework as shown in Figure 3 that caters to both the business risks and the SCM domino effect for a successful implementation of SCMI. SCM analytics is an integrated analytics mechanism that will enable supply chain personnel to make contextual and decisions dynamically based on integrated data mining and optimisation of supply chains. The descriptive analytics use historical data of the supply chain such as demand patterns to determine how the product flows through the supply chain. Similarly prescriptive analytics involves using data to suggest optimal solutions to supply chain problems in setting parameters such as inventory levels, product pricing, etc. Many organisations are able to employ descriptive and prescriptive analytics with software tools integrating the information flow in the supply chains to a certain extent. However, the SCMI domino effect could be more understood by adopting predictive analytics that can forecast future demand based on demand and supply uncertainties and various other environmental factors. It is important to combine predictive modelling and optimisation along with business intelligence (BI) using data mining techniques to perform "what-if" analysis for minimising the SCMI domino effect. Data mining techniques have been adopted successfully recently in a wide range of business situations, where the external factors fluctuate dynamically such as in the foreign exchange exposure problem (Mudogo \& Venkatraman, 2014).

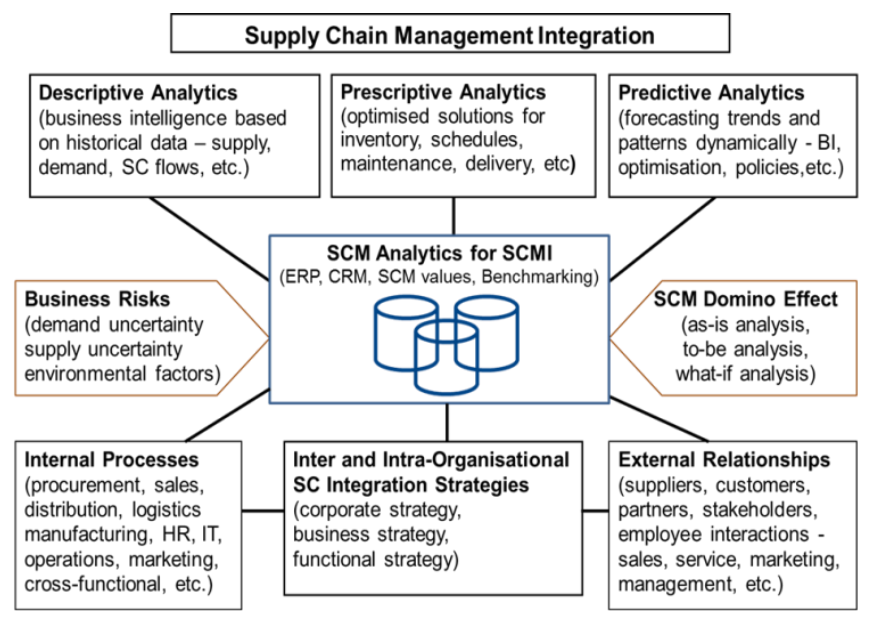

Figure 3 SCM Analytics Framework for SCM Integration

As shown in Figure 3, intra-organisational SC integration strategies aim at overcoming silo boundaries of internal processes at the corporate, business and functional levels. Material and information flows between departments such as procurement, sales, distribution, logistics, manufacturing, HR, marketing, etc. need to take place in a collaborative and cohesive manner through cross-functional integration of processes and systems. Information technology should be used effectively to bring functional units closer together. Similarly, inter-organisational SC integration strategies aim at external collaborations to overcome rigid organisational boundaries. External relationships of the company's employees and management with suppliers, customers, partners, stakeholders, etc. should be enhanced through the adoption of appropriate information and communication technologies at corporate, business and functional levels. This way, intraorganisational integration is aimed towards a wider supply chain network. As shown in Figure 3, our proposed SCM analytics framework provides the scope for achieving inter and intra-organisational SC integration of both internal processes and external relationships by making effective use of information and communication technologies in integrating processes, databases, and resource bases. Systems such as enterprise resource planning (ERP), customer relationship management (CRM), supply chain management (SCM), etc., across departments and organisations are integrated by establishing common values, 
standards and benchmarking, and by applying the descriptive, prescriptive and predictive analytics for making decisions dynamically. Such a holistic approach using abroader SCMI with ERP would alleviate SC silos and deliver greater efficiency and responsiveness to the entire business process of an organisation. For instance, a manufacturing company's ERP may require a particular scheduled delivery to customers, and integrating with the SCM analytics component could provide a more realistic delivery schedule that could be optimised by integrating with the CRM system in prioritising the order fulfillment. Such a proactive SCM analytics approach takes into account of business risks and SCM domino effect for evaluating and optimising material and information flows for achieving sustainability. Hence, the proposed SCM analytics framework for SCMI is aimed towards overcoming corporate, business and functional silos existing across the wider supply chain.

\section{CONCLUSIONS}

This study reveals important areas of concern in the organisations embarking on the implementation of the SCMI in their companies. The results from this study show that SCMI cannot be achieved easily before the effective adoption of the SCM concept, as a culture of the organisation. The research highlights the major problems indicated in Table $\mathbf{1}$ and the proposed solutions shown in Table 2 (see Appendix), based on an exploratory study conducted with supply chain personnel.

There is a need for an organisation to align SCMI to the company's corporate strategy, the possible demand and supply uncertainties as well as other environmental factors causing business risks, and these must be taken into consideration when planning the SCM. Critical problems and solutions should be handled carefully to avoid the SCMI domino effect on the organisation's performance. We proposed an SCM Analytics framework that caters to business risks and the SCM domino effect dynamically as shown in Figure 3.

Decision-makers should consider costs, benefits, and risks in the market environment before adapting the SCMI strategy. Technology alone cannot make a successful SCMI. There is a need to examine the big picture, especially difficult behavioural patterns and risks in implementing the SCMI. These are possible through predictive analytics. The inability to integrate SC members' procedures will slow the growth of SCM. Therefore, SCM should deal with the management of the entire supply chain. Descriptive and prescriptive analytics should be adopted for integrating the day-to-day operations of the supply chain and SCMI as a whole.

Although SCM can provide many benefits to the organisation, it requires reasonable investment and commitment. Thus, it is important to conduct a cost/benefit analysis, before adopting the SCMI strategy. There is a need for companies to align supply chain strategy with the corporate strategy, as recommended by Sahay, et al. (2003).

This exploratory study was conducted using online Internet discussion forum and will be useful to the supply chain management practitioners and researchers interested in understanding the current state of SCMI in various industry sectors, as well as its practical implementation. The SCM analytics framework for supply chain integration will be useful to the managers to improve the SCMI performance in an organisation, and researchers will be able to use the framework to conduct further in-depth studies on SCMI. The limitation of the study is a small sample used to identify SCMI problems and suggested solutions. The results cannot be generalised.

\section{FUTURE RESEARCH}

Our study has its limitations which create opportunities for future research. First, the validity of our proposed model needs to be empirically tested using a large sample in order to obtain results which can be generalised. Second, our three research models were used to explain the situation existing in a small convenience sample. Future studies should examine these models in detail using a large sample composed of various industry sectors to study if there are other key factors for SCMI in organisations and SCMI performance evaluation. Finally, as an ongoing research, there is a need to study the impact of business environment risks and the SCM domino effect on the SCMI Performance of organisations and determine the effective use of SCM Analytics Framework by the SCM practitioners.

\section{REFERENCES}

Bagchi, P.K., \& Chun, B. (2005). Supply chain integration: a European survey. The International Journal of Logistics Management, 16(20), pp. 275-294.

Bakker, F., Boehme, T., \& van Donk, D. (2012). Identifying barriers to internal supply chain integration using Systems Thinking. Proceedings of the 4th Production and Operations Management World Conference, pp. 1-10.

Basnet, C., Corner, J., Wisner, J., \& Tan, K-C. (2003). Benchmarking supply chain management practice in New Zealand. Supply Chain Management, 8(1), pp. 57-64.

Basnet, C. \& Wisner, J. (2012). Nurturing Internal Supply Chain Integration. Operations \& Supply Chain Management: An International Journal, 5 (1), pp. 27-41.

Boehme, T., Childerhouse, P., Deakins, E. \& Towill, D. (2011). Supply chain integration and pathways of least resistance. In U. Laptaned \& R. Banomyong (Eds.), Proceedings of the 3rd International Conference on Logistics and Transport \& The 4th International Conference on Operations and Supply Chain Management (ICLT \& OSCM 2011), pp. 453-462.

Bowersox, D.J., Closs, D.J., \& Stank, T.P. (1999). 21st century logistics: making supply chain integration a reality. Oak brook, Il: Council of Logistics Management.

Campbell, J.D. (2002). Evolution and assessment of supply chain integration: insights from leading NZ organisations, M.Com thesis, The University of Auckland.

Campbell, J. \& Sankaran, J. (2005). An Inductive framework for enhancing supply chain integration. International Journal of Production Research, 43(16), pp. 3321-3351.

Chatzoudes, D., \& Chatzoglou, P. (2011). The Impact of 360 Supply chain integration on operational and business performance, Operations and Supply Chain Management, 4(2/3), pp. 145-156.

Chong, A. Y. L., Chan, F. T. S., Ooi, K. B., \& Sim, J. J. (2011). Can Malaysian firms improve organizational/innovation performance via SCM? Industrial Management \& Data Systems, 111(3), pp. 410-431.

Delaney, R.V. (2000). Managing logistics in a perfect storm. Proceedings of the 12th Annual Press Conference presented at the National Press Club, Washington, DC.

Delaney, B. (1999). 10th annual 'State of Logistics Report.' St Louis, MO: Cass Information Systems. 
Donk, D.P.V., \& Vaart, T.V.E. (2005).A case of shared resources, uncertainty and supply chain integration in the process industry. International Journal of Production Economics, 96(1), pp. 97-108.

Eisenhardt, K.M., \& Graebner, M.E. (2007). Theory building from cases: opportunities and challenges. Academy of Management Journal, 50(1), pp. 25-32.

Flynn, B.B., Huo, B., \& Zhao, X. (2010), The impact of supply chain integration on performance: A contingency configuration approach., Journal of Operations Management, 28(1), pp. 58-71.

Frohlich, M.T. (2002). E-integration in the supply chain: barriers and performance. Decision Sciences, 33 (4), pp. 537-556.

Glaser, B.G., \& Strauss, A.L. (1967). The discovery of Grounded Theory. Strategies for Qualitative Research, Chicago: Aldine.

Glaser, B.G. (1992). Emergency vs. Forcing: Basics of Grounded Theory Analysis, Mill Valey, CA: Sociology Press.

Handfield, R.B., \& Nichols, E.L. Jr. (2002).Supply chain redesign transforming supply chains into integrated value systems. New Jersey: Prentice-Hall.

Hsu, C. C., Tan, K. C., Kannan, V. R. \& Leong, K. G. (2009). Supply chain management practices as a mediator of the relationship between operations capability and firm performance, International Journal of Production Research, 47 (3), pp. 835-55.

Georgise F.B., Thoben K., \& Seifert M. (2012), Adapting the SCOR Model to Suit the Different Scenarios: A Literature Review \& Research Agenda, International Journal of Business and Management, 7(6), pp. 2-13

Halldorsson, A., Larson, P. D., \& Poist, R. F. (2008), "Supply chain management: A comparison of Scandinavian and American perspectives," International Journal of Physical Distribution \& Logistics Management, 38(2), pp. 126-142.

Ho, C-F, Chi, Y-P., \& Tai, Y-M. (2005). A structural approach to measuring uncertainty in supply chains. International Journal of Electronic Commerce, 9(3), 91-114.

Hussain, A. H. A., \& Nassar, M. O., (2010). Supply Chain Integration: Definition and Challenges. Proceedings of Multinational Conference of Engineers and Computer Scientist, 1, Hong Kong.

Jabbour, A. B. L. d. S., Filho, A.G. M.Viana, A. B. N. and Jabbour, Ch. J. Ch. (2011). Measuring supply chain management practices, Measuring Business Excellence, 15 (2), pp. 18-31.

Koh, S. C. L., Demirbag, M., Bayaraktar, E., Tataglu, E., \& Zauim, S. (2007). The impact of supply chain management practices on performance of SMEs, Industrial Management \& Data Systems, 107(1), pp. 103-124.

Lambert, D.M., Cooper, M.C., \& Pagh, J.D. (1998). Supply chain management: implementation issues and research opportunities. The International Journal of Logistics Management, 9(2), pp. 1-19.

Lee, H.L., \& Whang, S. (1999, Fall). Supply chain integration in the age of e-business. Supply Chain Management Review, pp. 16-19.

Lee, H.L., \& Wolfe, M. (2003, January/February ). Supply chain security without tears. Supply Chain Management Review, $7(1)$, pp. $12-20$.

Lummus, R.R., \& Vokurka, R. J. (1999). Defining supply chain management: a historical perspective and practical guidelines, Industrial Management \& Data Systems, 99(1), pp. 11-17.

Kähkönen A., Lintukangas, N., \& Virolainen , K. (2013). The Effects of e-Business on Supply Management. Operations and Supply Chain Management 6(2), pp. 75-84.

Manzouri, M., Rahman, M. N. Ab., Arshad, H., \& Ghani, J. A. (2011). cutting down the difficulty of SCM implementation: a comparison between Iranian and Malaysian companies, Applied Mechanics and Materials, 44-47, pp.3652-3656.
Mentzer, J.T., DeWitt, W., Keebler, J.S., Min, S., Nix, N.W., Smith, C.D., \& Zacharia, Z.G. (2001). Defining supply chain management. Journal of Business Logistics, 22 (2), pp. 1-25.

Miah, S.J., Ahsan, K., \& Msimangira, K.A.B. (2013). An approach of purchasing decision support in healthcare supply chain management. Operations and Supply Chain Management, 6(2), pp. 43- 53.

Miguel, P. L. S., \& Brito, L. A. L. (2011). Supply chain management measurement and its influence on operational performance, Journal of Operations and Supply Chain Management, 4 (2), pp. 56 - 70.

Mollenkopf, D. \& Dapiran, G.P. (2005). World-class logistics: Australian and New Zealand. International Journal of Physical Distribution \& Logistics Management 35(1), 63-74.

Msimangira, K. A. B. (2006). Supply chain management integration practices: some problems and solutions. Proceedings of the 17th Annual Production and Operations Management Society (POMS) conference, Boston, Massachusetts, U.S.A.

Msimangira, K.A.B. (2010). Supply chain integration in New Zealand public hospitals: impact on supplier commercial relationships and order fulfilment. PhD thesis, Auckland University of Technology, New Zealand.

Msimangira, K.A.B., \& Tesha, C. (2014). Global supply chain management practices and risks facing developing countries: A case of Tanzania. Operations and Supply Chain Management: An International Journal (forthcoming).

Mudogo E.M., \& Venkatraman, S. (2014). Managing Foreign Exchange Exposure: Information System Integration. World Review of Business Research (forthcoming).

National Research Council. (2000). Surviving supply chain integration: strategies for small manufacturers. The National Academy of Sciences, pp. 27.

O'Dwyer J., \& Renner R. (2011). The promise of advanced supply chain analytics. Supply Chain Management Review, 15, pp. 32-37.

Oliva R., \& Watson N., (2011). Cross functional alignment in supply chain planning: A case study of sales \& operations planning, Journal of Operations Management, 29(5), pp.434448.

Olugu, E. U., \& Wong, K. Y. (2009). Supply Chain Performance Evaluation: Trends and Challenges. American Journal of Engineering and Applied Sciences, 2 (1), pp. 202-211.

Otchere, A. F., Annan, J., \& Anin, E. K., (2013) Achieving Competitive Advantage through Supply Chain Integration in the Cocoa Industry: A Case Study of Olam Ghana Limited and Produce Buying Company Limited. International Journal of Business and Social Research (IJBSR), 3(2), pp. 131-145.

Ou, C. S., Liu, F. C., Hung, Y. C., \& Yen, D. C., (2010). A structural model of supply chain management on firm performance. International Journal of Operations \& Production Management, 30 (5), pp. 526-545.

Pagell, M. (2004). Understanding the factors that enable and inhibit the integration of operations, purchasing and logistics. Journal of Operations Management, 22(5), 459-487.

Power, D. (2005). Supply chain management integration and implementation: a literature review. Supply Chain Management, 10(3/4), pp. 252-263

Richey Jr, R.G., Chen, H., Upreti, R., Fawcett, S.E., \& Adams, F. G. (2009). The moderating role of barriers on the relationship between drivers to supply chain integration and firm performance. International Journal of Physical Distribution \& Logistics Management, 39(10), pp. 826-840.

Sahay, B.S. \& Mohan, R. (2003). Supply chain management practices in Indian industry. International Journal of Physical Distribution \& Logistics Management, 33(7), pp. 582-606. 
Shen, T. (2005, pp. 58). Linking supply chain practices to operational and financial performance. MIT Supply Chain 2020 Project Working Paper. http:ctl.mit.edu/ visited on February 16, 2012.

Simchi-Levi, D., Kaminsky, P., \& Simchi-Levi, E. (2003). Designing and managing the supply chain: concepts, strategies, and case studies (second edition), Boston: Irwin/McGraw-Hill.

Soni, G., \& Kodaly, R., (2011). The strategic fit between "Competitive strategy" and "Supply chain strategy" in the Indian manufacturing industry: an empirical approach. Measuring Business Performance, Emerald Group Publishing Limited. 15 (2), pp. 70-80

Strauss, A., \& Corbin, J. (1998). Basics of qualitative research: techniques and procedures for developing grounded theory. Thousand Oaks, CA: Sage.

Stefanovic N., \& Stefanovic D. (2009). Supply chain business intelligence: Technologies, issues and trends, Articial Intelligence An International Perspective, M. Bramer ed., Lecture Notes in Computer Science, pp. 217-245.

Sweeney, E., (2011). Supply Chain Integration: Challenges and Solutions. Business Science Reference, pp. 585-588.

Stank, T.P., Keller, S.B., \& Closs, D. J. (2001). Performance benefits of supply chain logistical integration. Transportation Journal, 41(2/3), pp. 32-46.

Themistocleous, M., Irani, Z., \& Love, P.E.D. (2004). Evaluating the integration of supply chain information systems: A case study. European Journal of Operations Research, 159(2), pp. 393-405.

Towill, D.R., Childerhouse, P., \& Disney, S.M. (2000). Speeding up the progress curve towards effective supply chain management. Journal of Supply Chain Management, 5(3), pp. 122-130.

Valmohammadi, C. (2013). Investigating supply chain management practices in Iranian manufacturing organizations, Operations and Supply Chain Management, 6(1) pp. $36-42$.

Venkatraman, S., \& Nayak, R.R. (2014). Corporate sustainability: An IS approach for integrating triple bottom line elements. Social Responsibility Journal (forthcoming).

Venkatraman, S., \& Nayak, R.R. (2010). A performance framework for corporate sustainability. International Journal of Business Innovation and Research, 4(5), pp.475-490.

Vilasini, N., Neitzert, T. R., Rotimi, J. O. B., \& Windapo, A. O. (2012). A framework for sub-contractor integration in alliance contracts. International Journal of Construction Supply Chain Management, 2(1), pp. 17-33.

Wong, P.W., \& K.Y. Wong, (2007). Supply chain performance measurement system using DEA modeling. Industrial Management \& Data Systems, 107(3), pp. 361-381.

Yuva, J. (2000). Reducing costs through the supply chain. Purchasing Today, 11(6), pp. 48-63.

Zhou H., Benton W., Schilling D., \& Milligan G. (2011). Supply chain integration and the SCOR model, Journal of Business Logistics, 32(4), pp.332-344.

Kabossa A.B. Msimangira is a Senior Lecturer and Discipline Leader of business in the Department of Higher Education Business, Faculty of Business, Hospitality and Personal Services at the Northern Melbourne Institute of TAFE (NMIT), Australia. He received his B.A (Honours) (Production and Marketing Management) from the University of Dar es Salaam, Tanzania, an MBA (Operations Management) from the University of Arizona, U.S.A and a PhD (Supply Chain Management) from the Auckland University of Technology, New Zealand. He is a certified Fellow member of the Chartered Institute of Purchasing and Supply (FCIPS), U.K./Australia, and a certified Fellow member of the Chartered Institute of Marketing (FCIM), U.K. He has 34 years of experience in training, consultancy and research in the areas of purchasing / procurement, logistics, management, marketing, operations management, supply chain management, and supply chain integration. Kabossa has published research papers in peer reviewed international journals, including Operations and Supply Chain Management: An International Journal, Supply Chain Management: An International Journal, International Journal of Purchasing and Materials Management, the International Journal of Public Sector Management, and the international Journal of Sustainability Policy and Practice. Before joining NMIT, he worked at various universities, polytechnics and the United Nations.

Sitalakshmi Venkatraman has 25 years of academic experience in India, Singapore, New Zealand, and more recently in Australia since 2007. She currently works as Lecturer in the Department of Higher Education - Business, Faculty of Business, Hospitality and Personal Services at the Northern Melbourne Institute of TAFE (NMIT), Australia.She also serves as Member of Register of Experts at Australia's Tertiary Education Quality and Standards Agency (TEQSA). She has published seven book chapters and more than 80 research papers in internationally well-known refereed journals and conferences that include International Journal of Benchmarking, Information Sciences, International Journal of Business Information Systems, and Information Management \& Computer Security. She serves as Program Committee Member of several international conferences and Senior Member of professional societies and editorial board of international journals. 


\section{APPENDIX}

Table 1 Major SCM integration problems identified in the Forum

\begin{tabular}{|c|c|}
\hline Nature of problem & $\begin{array}{l}\text { Percentage of participant } \\
\text { comments on the problem }\end{array}$ \\
\hline $\begin{array}{l}\text { Insufficient training and competency levels required to maintain existing supply chain (SC) operations and to } \\
\text { support implementation of new technologies and increase efficiency }\end{array}$ & 50 \\
\hline Poor communication between SC members, especially primary members & 40 \\
\hline $\begin{array}{l}\text { Some members in the supply chain are dominant in the business relationship. Lack of trust, communication is } \\
\text { limited or formal, and information sharing becomes secretive. This leads to quality problems }\end{array}$ & 40 \\
\hline $\begin{array}{l}\text { Lack of internal cost efficiency and speed of delivery in the following areas: ordering, inventory, marketing, and } \\
\text { logistics }\end{array}$ & 40 \\
\hline Inadequate distribution channel design and structure i.e., balance of power in contractual relations & 30 \\
\hline Lack of a strong organisational culture committed to SCMI & 30 \\
\hline SC channel members view themselves as a collection of individual companies, not as a holistic system & 20 \\
\hline $\begin{array}{l}\text { The supply chain decision makers are usually not near the action i.e. the sales arena. Decisions are based on } \\
\text { inaccurate information }\end{array}$ & 20 \\
\hline $\begin{array}{l}\text { Supply chain process implementation is often hindered by technology overshadowing the human } \\
\text { resource and change management aspect }\end{array}$ & 20 \\
\hline Trade barriers between countries and government policies & 20 \\
\hline SC channel members do not share the same business values & 20 \\
\hline Company's suppliers serve their competitors and secret information could be revealed to the wrong party & 20 \\
\hline The flow of data between businesses is often insufficient or recorded on incompatible databases & 10 \\
\hline It is hard to have total control over the third party service provider's actions & 10 \\
\hline Poor internal communication of company's objectives cause communication breakdown: lack of effectiveness & 10 \\
\hline SC channel members fail to realize their contribution to customer satisfaction & 10 \\
\hline $\begin{array}{l}\text { Inadequate technology and lack of an integrated logistics System to support infrastructure requirements and } \\
\text { inter-channel commitments }\end{array}$ & 10 \\
\hline Under resourced (funding, technology, and personnel) & 10 \\
\hline
\end{tabular}

Table 2 Major SCM integration solutions identified in the Forum

\begin{tabular}{|l|c|}
\hline \multicolumn{1}{|c|}{ Nature of solution } & $\begin{array}{c}\text { Percentage of participant } \\
\text { proposing this solution }\end{array}$ \\
\hline $\begin{array}{l}\text { Two-way communication is needed, and everyone involved in the SCMI must be aware of the structure and } \\
\text { processes involved in the SC. Information sharing is important }\end{array}$ & 60 \\
\hline $\begin{array}{l}\text { Integrating key members' interactions of the supply chain requires a holistic approach and adoption from top } \\
\text { executives to shop floor members for efficient and effective change }\end{array}$ & 40 \\
\hline Form strategic alliances with SC members, and foster an open and honest culture & 30 \\
\hline $\begin{array}{l}\text { Members in the SC would benefit from integrating SCM software systems, using compatible operating } \\
\text { systems and hardware }\end{array}$ & 20 \\
\hline $\begin{array}{l}\text { There is a need to have integrated SCM processes, taking into account their impact on the operations of an } \\
\text { organisation }\end{array}$ & 20 \\
\hline $\begin{array}{l}\text { There is a need to constantly monitor new technologies and software solutions, and conduct the cost/benefit } \\
\text { analysis for SC. The cost of change management must be examined }\end{array}$ & 20 \\
\hline $\begin{array}{l}\text { There is a need to establish written service level agreements for third party suppliers, and review them on } \\
\text { quarterly basis. Also, monthly client surveys must be carried out to monitor their level of professionalism and } \\
\text { efficiency }\end{array}$ & 10 \\
\hline Relationship management is required to reinforce written service level agreements and company's strategy & 10 \\
\hline Form strategic alliances where all SC parties can reap the benefits & 10 \\
\hline $\begin{array}{l}\text { Develop standards and responsibilities for each SC member, have regular meetings, discuss problems and } \\
\text { opportunities, and encourage two-way communication }\end{array}$ & 10 \\
\hline Define clear lines of responsibility and performance expectations in the SC & 10 \\
\hline $\begin{array}{l}\text { Emphasise on relationship management, performance measurement, control of processes, and continuous } \\
\text { improvement }\end{array}$ & 10 \\
\hline An organisation must be innovative & 10 \\
\hline
\end{tabular}

